\title{
RELASI KONFILK DAN AGAMA \\ STUDI TENTANG MODEL PENYELESAIAN KONFLIK \\ KEGAMAAN
}

\author{
Asnawan \\ Dosen IAI Al Falah As Sunnniyyah Kencong Jember \\ asnawanwan@gmail.com
}

\begin{abstract}
Several attempts to resolve the Sunni-Shi'a conflict pursued by various postconflict groups include: 1) coordination meetings at the Muspida level by involving various elements in order to reduce wider conflict; 2) increase the intensity of communication between ethnic groups and groups in an effort to anticipate provocative issues; 3 ) crack down on the perpetrators and the brain of riots through efforts to find, detain
\end{abstract}

Keywords: conflict, religion, Sunni-Shi'ah

\section{PENDAHULUAN}

Studi tentang konflik sosial senantiasa menarik untuk dibahas dan dikaji bahkan diteliti, terutama pada masyarakat yang sedang mengalami perubahan. Karena masyarakat yang mengalami perubahan, akan mengalami dinamika dan gesekan-gesekan yang dapat melahirkan konflik, baik yang bersifat horizontal (antar masyarakat) maupun vertikal (masyarakat dengan pemerintah). Tidak terkecuali di Indonesia, seperti yang kita ketahui bersama Indonesia kental dengan ciri masyarakat plural dan heterogen yang terdiri dari berbagai, suku, agama, etnis, budaya, paham, ideologi dan kelompok dan atau golongan. ${ }^{1}$ Negara Kesatuan Republik Indonesia telah menyadari arti pentingnya Hak Asasi Manusia (HAM) sebagai konsep yang mendasari suatu negara hukum. Undang-undang Dasar 1945 telah membuat nilai-nilai HAM pada pembukaan dan pasal-pasalnya yaitu pasal 27

${ }^{1}$ Hasrullah, Dendam Konflik Poso (Jakarta: Gramedia Pustaka Utama, 2009), 1. dalam Undang-undang Republik Indonesia Nomor 7 Tahun 2012 tentang Penanganan Konflik social juga dijelaskan tentang sumber sumber konflik yaitu pada Pasal 5 yang berbunyi a). permasalahan yang berkaitan dengan politik, ekonomi, dan sosial budaya; b). perseteruan antarumat beragama dan/atau interumat beragama, antarsuku, dan antaretnis; c). sengketa batas wilayah desa, kabupaten/kota, dan/atau provinsi; d). sengketa sumber daya alam antarmasyarakat dan/atau antarmasyarakat dengan pelaku usaha; atau e). distribusi sumber daya alam yang tidak seimbang dalam masyarakat.

FalASIFA, Vol. 9 Nomor 1 Maret 2018 | 129 
Asnawan

sampai dengan pasal 31. Di dalam pasal 27 ayat (1), menerangkan bahwa "segala warga Negara bersamaan kedudukannya di dalam hukum dan pemerintahan dan wajib menjunjung bukum dan pemerintaban itu dengan tidak terkecuali”. Berdasarkan pasal 27, butir (1) Undang-undang Dasar 1945 tersebut, di Indonesia tidak boleh ada diskriminasi hukum terhadap warga negaranya. ${ }^{2}$

Selanjutnya dalam UU Nomor 39 Tahun 1999 Tentang Hak-Hak Azazi Manusia (HAM) masalah kebebasan dan kerukunan umat beragama di atur pada Pasal 22 dan 70. Dalam Pasal 22 dikatakan bahwa setiap orang mempunyai hak kebebasan untuk memeluk suatu agama dan beribadat menurut agama dan kepercayaannya itu; Negara menjamin kebebasan bagi setiap orang untuk memeluk dan mengamalkan agamanya serta beribadat menurut agama dan kepercayaannya itu. Kemudian pada Pasal 70 UU itu dikatakan bahwa dalam menjalankan hak dan kewajibannya itu, setiap orang wajib mengacu kepada pembatasan semata-mata untuk menjamin penghargaan kepada hak dan kebebasan orang lain dan penegakkan keadilan, serta memperhatikan pertimbangan moral, keamanan, dan ketertiban masyarakat dalam suatu masyarakat yang demokratis.

Dengan deretan-deretan peraturan dan perundang-undangan yang telah dipaparkan di atas, mengindikasikan bahwa Indonesia seakan sudah tidak kenal yang namanya konflik bahkan kekerasan. Akan tetapi, konflik sosial di Indonesia bergulir sejak tahun 1990 menunjukkan eskalasi yang cukup tinggi. Latar belakang konflik sosial tersebut antara lain; pertama, konflik antarkelompok masyarakat; kedua, konflik antar suku atau antar dan intra agama; ketiga, konflik antara masyarakat dengan pemerintah dengan latar belakang kasus-kasus tertentu. Konflik sosial bermotif agama acapkali terjadi di sekitar kita yang notabennya umat beragama, baik itu internal agama ataupun antar agama. ${ }^{3}$ Meskipun konflik sosial yang terjadi tidak secara mutlak disebut sebagai konflik agama, dengan alasan konflik itu tidak dilakukan atas dasar bernuansa agama. Tetapi hal itu tidak berarti bahwa unsur-unsur agama tidak dilibatkan dalam konflik-konflik tersebut.

Tidak dapat dipungkiri bahwa beberapa tahun terakhir ini, di Indonesia menjadi salah satu kawasan di dunia yang paling produktif dalam memproduksi aneka kisah tragis di sekitar kekerasan. Selama 14 tahun setelah reformasi, setidaknya ada 2.398 kasus kekerasan dan diskriminasi yang terjadi di Indonesia.

2 Robert Alexander, Konflik Antar Entis dan Penanggulangannya" (Tesis, Universitas Diponegoro, Semarang, 2005), 1

${ }^{3}$ Sandi Suwardi Hasan, Konflik Sosial dan Urgensi Dialog Agama”, al-'Adalah, 2 (Jember: STAIN Press, 2007), 240 lihat juga Ayu Sutarto, Menjadi NU menjadi Indonesia (Jember, Kopyawisda Jatim, 2005), 77

$130 \mid$ FaLASIFA, Vol. 9 Nomor 1 Maret 2018 
Yayasan Denny JA mencatat, dari jumlah itu paling banyak kekerasan terjadi karena berlatar agama/paham agama sebanyak 65 persen. Sisanya, secara berturutturut adalah kekerasan etnis (20 persen), kekerasan jender (15 persen), dan kekerasan orientasi seksual (5 persen). ${ }^{4}$ Fenomena-fenomena semacam itu, sangatlah bertentangan dengan tradisi khas bangsa Indonesia, gotong royong, musyawarah rukun dan tolong menolong. ${ }^{5}$ Merujuk pada Kovenan Internasional Hak Sipil dan Politik sebagaimana yang sudah diratifikasi (menjadi hukum nasional Indonesia) melalui UU no 12 tahun 2005, idealnya negara memiliki kewajiban untuk melindungi kebebasan hak sipil dan politik warga negaranya, lebih utamanya hak dan kebebasan yang mendasar seperti hak untuk hidup, hak untuk tidak disiksa dan hak atas keadilan. Namun dalam kenyataannya, alih-alih terlindungi yang terjadi justru kekerasan dan melanggar kebebasan sipil dan politik warga negara. ${ }^{6}$

Dalam kurun waktu hampir 19 tahun, insiden kekerasan terkait konflik keagamaan di Indonesia telah melibatkan korban jiwa lebih dari 55.000 orang. Di antaranya, 761 orang merupakan korban tewas, 1873 orang merupakan korban luka-luka dan sebanyak 52.446 orang merupakan korban hilang dan mengungsi. Adapun dari segi harta benda, kekerasan terkait isu-isu keagamaan di Indonesia telah mengakibatkan rusaknya 1.330 rumah, 70 rumah ibadah dan 593 bangunan lainnya, sehingga totalnya mencapai 1.993 bangunan. Jumlah kerugian hartabenda tersebut belum termasuk jenis kendaraan bermotor, baik roda dua maupun empat, serta berbagai kerugian yang tidak dilaporkan secara jelas jumlahnya oleh media yang menjadi sumber studi ini. ${ }^{7}$

Adapun catatan kasus pelanggaran kebebasan beragama atau berkeyakinan di Indonesia selama tahun 2011 yang paling tinggi adalah pelarangan atau pembatasan aktifitas keagamaan atau kegiatan ibadah kelompok tertentu dengan 49 kasus, atau $48 \%$, kemudian tindakan intimidasi dan ancaman kekerasan oleh aparat negara 20 kasus atau 20\%, pembiaran kekerasan 11 kasus (11\%), kekerasan dan pemaksaan keyakinan 9 kasus (9\%), penyegelan dan pelarangan rumah ibadah

${ }^{4}$ Sabrina Asril, "Catatan Kekerasan Indonesia pasca Reformasi", dalam http://lahmadiyah.blogspot.com/2013/01/catatan-kekerasan-indonesia-pasca.html

${ }^{5}$ Slamet Sutrisno, Filsafat dan Ideologi Pancasila (Yogyakarta: ANDI, 2006), 63

${ }^{6}$ Komisi untuk Orang Hilang dan Korban Tindak Kekerasan (KontraS), "Keadilan Macet, Kekerasan Jalan Terus : Laporan Tahunan Kondisi HAM di Indonesia 2012" (tt,tp, 2013), 14

${ }^{7}$ Ihsan dkk, Pola-pola Konflik Keagamaan di Indonesia (1990-2008), (hasil penelitian yang bekerjasama Yayasan Wakaf Paramadina (YWP) Magister Perdamaian dan Resolusi Konflik, Universitas Gadjah Mada (MPRK-UGM), The Asia Foundation (TAF), Jakarta, 2009), 31-32

FaLASIFA, Vol. 9 Nomor 1 Maret 2018 | 131 
Asnawan

9 kasus (9\%), dan kriminalisasi atau viktimisasi keyakinan 4 kasus (4\%). Berdasarkan data ini dapat dipahami bahwa selama tahun 2011, telah terjadi peningkatan pelanggaran kebebasan beragama dan berkeyakinan di berbagai daerah di Indonesia. Apabila tahun sebelumnya hanya 64 kasus maka jumlah ini meningkat $18 \%$ menjadi 92 kasus. ${ }^{8}$

Konflik bernuansa agama dalam panggung sejarah sejak pertama kali ditunjukkan oleh Habil dan Qabil. Konflik tersebut seyogyanya bukan konflik agama, akan tetapi oleh para sejarawan dikaitkan dengan agama, bahwa konflik yang berujung pada pembunuhan itu ditunjukkan oleh Islam. Padahal konflik Habil dan Qabil adalah konflik sosial yang berskala kecil, yakni karena penolakan Qabil terhadap titah ayahnya, karena Qabil ingin mengawini saudara perempuannya sendiri. ${ }^{9}$ Kisah Habil dan Qabil merupakan sumber filsafat kita, sebagaimana Adam sebagai sumber filsafat sejarah kita tentang manusia. Pertarungan antara Habil dan Qabil adalah pertarungan dua kubu yang saling berlawanan yang berlangsung sepanjang sejarah, dalam dialektika sejarah ${ }^{10}$ Bukankah kisah para nabi juga tak lepas dari wacana kekerasan? Nabi Yusuf, misalnya, dikisahkan menghadapi dan menjadi korban rencana kekerasan saudara-saudara kandungnya sendiri. Nabi Isa yang diintai oleh ancaman pembunuhan, yang dalam tradisi Yudeo-Kristiani, bahkan kemudia diyakini menjadi korban kekerasan. Nabi Muhammad sempat memasuki 'aamul buzn masa sedih, lantaran kehilangan orang yang dapat member rasa aman, sementara Ia masih harus menghadapi resistensi paman-pamannya sendiri, boikot, terror dan bahkan pengejaran oleh suku Quraisy yang hendak membunuhnya. ${ }^{11}$ Konflik dalam tubuh umat Islam di Indonesia, barangkali hanya sekedar aib yang harus ditutupi manakala terjadi sesaat atau tidak banyak korbannya. Tetapi manakala peristiwa itu sudah mengorbankan sendi-sendi kebersamaan dan ukhuwah, perlu kiranya dijadikan pelajaran. Dari kasus yang dipicu oleh persaingan (competition) usaha, perebutan warisan, hingga pengrusakan rumah ibadah dan pembantaian

8 http://alislamiyah.uii.ac.id/2013/08/22/menguak-akar-kekerasan-bernuansaagama/\#_ftn4 lihat juga The Wahid Institute, "Lampu Merah Kebebasan Beragama", Laporan Kebebasan Beragama dan Toleransi di Indonesia, (Jakarta: The Wahid Institute, 2011), 1

9 Ibnu Katsir, Kisah Habil dan Qabil (Dar Al-Manarah) dalam ebook www.Islambasics.com

${ }^{10}$ Imam B. Jauhari, Teori Sosial: Proses Islamisasi dalam Sistem Ilmu Pengetahuan, Yogyakarta:Pustaka Pelajar, 2012), 49

${ }^{11}$ Abdul Munir Mulkan, dkk, Membongkar Praktik Kekerasan: menggagas Kultur Nir-Kekerasan (Malang: Universitas Muhammadiyah Malang, 2002), 43

132 | ALASIFA, Vol. 9 Nomor 1 Maret 2018 
pemuka agama, sudah sering terjadi. Tuduhan terhadap kelompok atau aliran sesat dalam agama, biasanya yang kemudian menimbulkan kerawanan internal. ${ }^{12}$

Ada satu hal menarik yang perlu digaris bawahi. Bahwa di Indonesia, agama Islam menjadi agama mayoritas. Menurut Abul A'la Al Maududi sebagai mana dikutib oleh Afif Muhammad, tekanan mayoritas atas minoritas hampir seluruhnya terjadi di Negara-negara yang mayoritas warganya bukan muslim. Sementara di Negara-negara yang mayoritas warganya muslim, penindasan hampir tidak pernah terjadi. Bahkan beberapa sarjana muslim mengatakan bahwa, berbeda dengan agama Islam, agama-agama non-Islam khususnya Katolik dan Kristen tidak memiliki ajaran tentang toleransi. ${ }^{13}$

Pada tahun 2003, Muktamar Pemikiran Islam Nahdlatul Ulama (MPI-NU) yang diselenggarakan di Situbondo, menghasilkan hal yang sejalan dengan pernyataan Afif yaitu, mencoba untuk melihat doktrin-doktrin keIslaman bukan hanya sebagai hukum, melainkan sebagai etika sosial yang bisa diterima oleh seluruh umat manusia, apa pun agama, suku dan rasnya. Sejatinya, keislaman tidak hanya dibatasi oleh dan untuk umat (rahmatan li al-'alamin). Islam sebagai etika sosial merupakan jalan untuk mengukuhkan semangat kebangsaan. ${ }^{14}$

Pernyataan Abul A'la Al Maududi tersebut tidak salah akan tetapi tidak sepenuhnya benar. Faktanya, agama Islam di Indonesia merupakan agama mayoritas, kita mengetahui bahwa mayoritas penduduk Indonesia beragama Islam (88\%), selebihnya adalah Kristen Protestan (6\%), Katolik (3\%), Hindu (2\%), Budha, Konghucu dan lainnya $(1 \%)^{15}$, akan tetapi Islam hampir tidak pernah absen dalam menyumbang catatan konflik yang berwujud kekerasan/penindasan. Misalkan di Manado, Maluku Utara pada tahun 2000, atau yang dikenal dengan kerusuhan 171 karena terjadi pada tanggal 17 bulan 1 (Januari), pada waktu itu

\footnotetext{
${ }^{12}$ Tim Balai Litbang, Mencari Solusi Konflik dan Kekerasan Internal Umat Islam dalam http://www.balitbangdiklat.kemenag.go.id/sinopsis-hasil-penelitian/kehidupanberagama/283-mencari-solusi-konflik-dan-kekerasan-internal-umat-beragama.html

${ }^{13}$ Afif Muhammad, Agama \& Konflik Sosial (Bandung: MARJA, 2013), 19

${ }^{14}$ Rizqon Khamami, Tashwirul Afkar (Jakarta Selatan: LAKPESDAM dan TAF, 2004), 41 edisi nomor 17. Selain itu, Harun Nasution, dalam Islam Ditinjan dari Berbagai Perspektif (Jakarta: Universitas Indonesia Press, 2002), 97 menyinggung hal syariat pun, pemikiran yang ditawarkan Al-Tahtawi, syari'at itu sendiri harus disesuaikan dengan perkembangan modern.

${ }^{15}$ M. Atho Mudzhar, "Lingkungan Dan Peran Strategis Fkub Dalam Pemeliharaan Kerukunan Umat Beragama Dan Persatuan Nasional” dalam ,http://balitbangdiklat. kemenag.go.id/indeks/artikel-ilmiah/593--lingkungan-dan-peran-strategis-fkub.html
}

FaLASIFA, Vol. 9 Nomor 1 Maret 2018 | 133 
Asnawan

umat Islam sebanyak 76,47\%, umat Hindhu $17,55 \%$, Kristen 2,5\% dan Budha $2 \% .^{16}$

Bahkan lebih parahnya lagi, umat Islam saling merusak terhadap sesesama muslimnya. Konflik kekerasan terhadap pengikut Ahmadiyah di Cikeusik pada pada 6 Februari 2011 dan juga konflik Ahmadiyah di Transito Mataram ${ }^{17}$, bahkan beberapa bulan terakhir kekerasan antar Islam juga terjadi di Sampang-Madura pada tahun 2012 yakni kekerasan terhadap pengikut syi'ah. ${ }^{18}$ Dan disusul oleh konflik yang tidak jauh beda, yakni konflik yang melibatkan isu Syi'ah dan Sunni di Kecamatan Puger Kabupaten Jember yang berujung pada kematian. Namun perkembangan yang cukup menggembirakan muncul kemudian dengan adanya upaya-upaya yang lebih serius baik dari inisiatif pemerintah maupun masyarakat untuk memperkuat peace building dengan upayapembangunan kembali kehidupan masyarakat di daerah berkonflik. ${ }^{19}$ Dengan demikian, tidak terlalu salah pendapat yang mengatakan bahwa ketegangan yang muncul belakangan ini menunjukkan betapa tidak sejatinya harmoni antar sesama Islam yang saling berinteraksi dalam kehidupan bermasyarakat. Bahkan hal ini menunjukkan betapa rapuhnya relasi dalam lingkup keagamaan khusunya dalam agama Islam yang selama ini kita banggakan. Pada makalah ini, penulis ingin membongkar praktik kekerasan yang terjadi di wilayah. Konflik sosial di kecamatan Puger ini sejatinya bukan hanya terjadi satu kali, melainkan sudah berlangsung beberapa kali, misalkan pada bulan Juni 2012 dengan motif pengajian yang berujung cederanya beberapa warga, dilanjutkan pada tahun berikutnya, yakni 2013 pada bulan September yang dikemas dengan karnaval dan berujung pada korban nyawa seseorang ${ }^{20}$. Menurut KH hasyim Muzadi, mantan ketua PBNU, konflik tersebut bisa jadi seperti bom waktu yang dapat meledak lagi kapan saja, untuk itu beliau meminta agar konflik di Puger tersebut diselesaikan sampai ke akar-akarnya. ${ }^{21}$

${ }^{16}$ Tim Balai Litbang, Konflik-konflik Sosial Bermuansa SARA di Berbagai Komunitas. Dalam http://www.balitbangdiklat.kemenag.go.id/sinopsis-hasil-penelitian/kehidupanberagama/172-konflik-konflik-sosial-bernuansa-sara-di-berbagai-komunitas-studi-kasuskerusuhan-mataram-januari-2000.html

${ }^{17}$ Sabrina Asril, Catatan Kekerasan Indonesia Pasca Reformasi, dalam http://lahmadiyah.blogspot.com/2013/01/catatan-kekerasan-indonesia-pasca.html

${ }^{18}$ http://www.tribunnews.com/nasional/2013/08/26/pengusutan-kasus-sampanghasilkan-14-butir-kesimpulan

19 Syafuan Rozi, Kekerasan Komunal:Anatomi dan Resolusi Konflik di Indonesia (Yogyakarta: Pustaka Pelajar, 2006), 6

${ }^{20}$ Radar Jember, Karnaval Rusuh, Satu Tewas, tanggal 12 September 2013,1

${ }^{21}$ Radar Jember, Satu Menyerah di Lumajang, tanggal 17 September 2013

134 | ҒaLASIFA, Vol. 9 Nomor 1 Maret 2018 


\section{PEMBAHASAN}

\section{KONFLIK ANTAR KELOMPOK DAN KEKERASAN SOSIAL}

Cakupan bahasan konflik antarkelompok, Walter G. Stephan dan Cookie White Stephan yang dikutip oleh Hasrullah, manawarkan tiga teori tentang konflik antarkelompok, yaitu ${ }^{22}$ : (1) Realistic Group Conflict Theory. Teori ini mempunyai premis yang didasari oleh kompetisi untuk memperebutkan resources (land, money, natural resources) atau pun value, belief dan norms. Teori realistic ini digunakan untuk memprediksi konsekuensi psikologis, di mana realitas konflik kelompok memicu meningkatnya kohesivitas dan etnosentrisme antarkelompok. Perubahan ini biasanya diiringi dengan kekerasan terhadap kelompok lain. (2) Relative Deprivation Theory, teori ini cenderung menfokuskan diri pada persepsi, yakni persepsi menjadi kelompok yang kurang beruntung. Seperti yang dikemukakan Thomas, persepsi merasa tertindas dapat amemicu munculnya konflik, meskipun pada persepsi yang dirasakan belum tentu kebenarannya. Konsep teori ini cenderung mempunyai kaitan dengan teori pertukaran sosial (social exchange theory) karena dalam cakupan bahasannya, konflik muncul dari perasaan dalam suatu kelompok yang merasa kurang beruntung ditinjau dari segi input dan output-nya jika disbandingkan kelompok lain. (3) Basic Psychological Need Theory. Teori ini menekankan adanya pertikaian dalam pemenuhan kebutuhan dasar psikis. Isu yang dimunculkan dalam teori ini adalah konflik muncul karena terjadi pembohongan kebutuhan psikis seperti; rasa aman, identitas, pengakuan, dan pastisipasi. Konflik yang dilandasi oleh kebutuhan psikis cenderung bertahan cukup lama hingga kebutuhan tersebut dapat terpenuhi.

Dalam kamus pupuler bahasa Indonesia, konflik percekcokan, perselisihan, pertentangan. Sedangkan menurut Webster, istilah konflik merupakan konfrontasi fisik antara beberapa pihak. Akan tetapi kata tersebut kemudian berkembang dengan masuknya "ketidaksepakatan yang tajam atau oposisi atas berbagai kepentingan, ide dan lain-lain". ${ }^{23}$ Sedangkan dalam Oxford Dictionary sebagaimana dikutip oleh Alpha Amirachman konflik adalah a situation in which people, groups or countries are involved in a serious disagreement or argument (situasi dimana orangorang, kelompok atau Negara terlibat dalam perselisihan serius). ${ }^{24}$

Berkenaan dengan konflik, secara teoritik menurut Ralf Dahren Dorf yang dikutip oleh Rozi, merupakan fenomena yang selalu hadir (inherent omni-presence)

\footnotetext{
${ }^{22}$ Hasrullah, Konflik Poso, 43

${ }^{23}$ Dean G. Pruitt dan Jeffrey Z. Rubin. Teori Konflik Sosial (Yogyakarta:Pustaka Pelajar,2004) 9

${ }^{24}$ Alpha Amirrachman. Revitalisasi Kearifan Lokal (Jakarta Selatan: ICIP, 2007) 2
}

FaLASIFA, Vol. 9 Nomor 1 Maret $2018 \mid 135$ 
Asnawan

dalam setiap masyarakat manusia. Menurutnya, perbedaan pandangan dan kepentingan diantara kelompok-kelompok masyarakat tersebut merupakan hal yang cenderung alamiah dan tidak terhindarkan. Namun pihak yang menolak sudut pandang ini mengatakan bahwa akan menjadi persoalan besar tatkala cara untuk mengekpresikan perbedaan kepentingan diwujudkan dalam ekspresi yang tidak demokratis dan merusak melalui penggunaan cara kekerasan fisik. ${ }^{25}$ Definisi klasik mengenai konflik adalah seperti dikemukan Louis Coser, yaitu: "a struggle over values and claims to secure status, power, and resources, a struggle in which the main aims of opponents are to neutralize, injure, or eliminate rivals".

Namun, untuk kepentingan studi ini, definisi ini dianggap masih terlalu umum dan tampaknya lebih didasari atasrasionalitas tindakan dengan motif ekonomi-politik. Ini kurang cocok untuk studi ini karena, seperti yang telah ditunjukkan oleh beberapa studi, aksi keagamaan - termasuk dalam konteks konflik dan kekerasan - sulit untuk dipahami semata-mata dari segi rasionalitas ekonomi dan politik atau kekuasaan. Berbagai tindakan protes atau kekerasan terkait konflik keagamaan banyak berasal dari sumber-sumber kultural dan ideologis agama itu sendiri, dan rasionalitas yang mendasari konflik tersebut lebih bersifat ekspresif atau simbolik; misalnya, sebagai ekspresi dari apa yang dipahami suatu komunitas agama sebagai "ketaatan" terhadap ajaran agama atau sebagai simbol solidaritas terhadap komunitas. ${ }^{26}$

Menurut Mitchell yang dikutib oleh Suharno, konflik dapat diartikan sebagai hubungan antar dua pihak atau lebih (individu maupun kelompok) yang memiliki atau merasa memiliki-sasaran-sasaran yang tidak sejalan. ${ }^{27}$ Jocye Hocker dan William Wilmut, di dalam buku Interpersonal Conflict, menjelaskan beberapa pandangan tentang konflik, pandangan-pandangan tersebut antara lain: ${ }^{28}$

1. Konflik adalah hal yang abnormal karena hal yang normal ialah keselarasan. Mereka yang menganut pandangan ini pada dasarnya termasuk menyampaikan bahwa suatu konflik hanyalah merupakan gangguan stabilitas. Karena konflikdilihat sebagai suatu gangguan, maka harus diselesaikan segera, apapun penyebabnya (walaupun mungkin saja terjadi bahwa penyebabnya yang terdalam tidak ditemukan).

${ }^{25}$ Syafuan Rozi dkk, Kekerasan Komunal (Yogyakarta: Pustaka Pelajar, 2004), 5

${ }^{26}$ Ihsan dkk, Pola-pola Konflik Keagamaan di Indonesia (1990-2008), 7.

${ }^{27}$ Kutipan ini diambil dari makalah Suharno yang disampaikan dalam Seminar dan Lokakarya Resolusi Konflik pada Civics Community, "Konflik, Etnisitas dan Integrasi Sosial" (Universitas Negeri Yogyakarta, 2006), 2

${ }^{28}$ Robby I. Candra, Konflik dalam hidup sehari-hari, (tt, Kanisius tahun,1992), 15 
2. Konflik sebenarnya hanyalah suatu perbedaan atau salah paham. Kata-kata serupa itu sering kali disampaikan oleh orang-orang yang terlibat dalam sebuah konflik. Dengan kata lain, konflik tidak dinilai sebagai hal yang terlalu serius. Bahkan menurut penganut pendapat ini, penyebab konflik ialah kegagalan berkomunikasi dengan baik, sehingga pihak lain tidak dapat memahami maksud kita yang sesungguhnya.

3. Konflik adalah gangguan yang hanya terjadi karena kelakuan orang-orang yang tidak beres. Pendapat ini sering pula diungkapkan dengan cara lain. Orang-orang yang senang terlibat konflik adalah anti-sosial paranoid, ngawur atau senang berkelahi. Menurut penganut pendapat ini, penyebab suatu konflik adalah ketidakberesan kejiwaan orang tertentu.

Menurut Haryanto sebagaimana dikutip oleh Nurman Said, perbedaan kepentingan, faham, ide merupakan keniscayaan dalam kehidupan, maka sudah dapat dipastikan konflik menjadi sesuatu yang selalu hadir sepanjang perjalanan kehidupan masyarakat tersebut. Namun dalam melihat konflik yang terjadi di masyarakat perlu dibedakan antara konflik yang menggunakan kekerasan (violence), dengan konflik yang tidak menggunakan kekerasan (non-violence). ${ }^{29}$

Secara umum, Pruitt dan Gahagan membagi konflik dalam tiga model, yaitu antara lain:

1. Model Aggressor-Defender

Model ini menarik garis pembeda di antara kedua belah pihak yang berkonflik, salah satu pihak, aggressor (penyerang) dianggap memiliki suatu tujuan atau sejumlah tujuan yang mengakibatkannya terlibat di dalam konflik bersama pihak lain defender (pihak bertahan).$^{30}$ Istilah agresor dam defender di dalam model ini tidak dimaksudkan sebagai tidakan evaluatif. Dengan perkataan lain, istilah-istilah ini tidak menyiratkan bahwa satu pihak dalam posisi salah dan pihak lainnya benar di dalam kontroversi yang terjadi. Agresor adalah pihak yang melihat adanya kesempatan untuk mengubah hal-hal yang searah dengan kepentingannya, sedangkan defender adalah pihak yang berusaha menolak perubahan tersebut. ${ }^{31}$

2. Spiral-Konflik

Model ini menjelaskan bahwa eskalasi merupakan hasil dari suatu lingkaran setan antara aksi dan reaksi. Taktik-taktik contentious yang dilakukan oleh suatu

${ }^{29}$ Nurman Said, Masyarakat Muslim Makasar (Jakarta: Badan Litbang dan Diklat Departemen Agama RI, 2009), 26

${ }^{30}$ Dean G. Pruit dan Jeffrey Z. Rubin, Teori Konflik Sosial, 200

${ }^{31}$ Dean G. Pruit dan Jeffrey Z. Rubin, Teori Konflik Sosial , 201

FaLASIFA, Vol. 9 Nomor 1 Maret 2018 | 137 


\section{Asnawan}

pihak mendorong timbulnya respons contentious dari pihak lain, sehingga lebih lanjut juga memberikan respon contentious dari pihak yang bersangkutan (pihak lawan). Ada dua kelompok besar spiral-konflik, spiral yang bersifat balas-membalas (retaliatory), masing-masing pihak menjatuhkan hukuman kepada pihak yang lain atas tindakan-tindakannya yang dianggap tidak menyenangkan (aversif). Misalkan, adu argumentasi yang diikuti dengan saling membentak kemudian diikuti dengan adu jotos bahkan bisa jadi lebih dari itu. Ada juga spiral yang defensif, masing-masing pihak memberikan reaksi dalam rangka melindungi diri dari ancaman yang dirasakannya ada di dalam tindakan defensif pihak lain. Mereka yang menderita (suffering) karena kekerasan yang dilakukan pihak lain, bisa membuat penderitaan balasan, sehingga terjadilah kekerasan secara timbale balik. Oleh karena itu, kekerasan bukan saja bisa menimbulkan penderitaan dalam jangka pendek, melainkan bisa juga menimbulkan menimbulkan penderitaan akibat kekerasan secara proses social dan konjungtif atau bahkan permanen -seperti yang dialami oleh orang-orang korban perang Israel-Palestina, Nazi-Yahudi, korban Perang Salib atau penderitaan akibat kolonialisme dan berbagai perang saudara di banyak negeri. Tentu saja, termasuk perang saudara atau keonflik etnisitas dan keagamaan di negeri kita sendiri yang terjadi padaa 1948, 1965, dan juga akhir-akhir ini. ${ }^{32}$ Dalam kaitannya dengan Konflik Agama, Yusuf Qardhawi mengatakan, untuk mempertemukan kedua kelompok ini, sepatutnya memperingatkan kedua

pihak berkonflik -yang tersesat jauh dari agamanya- agar segera kembali ke jalan tengah yang moderat, untuk mendorong kaum ekstrem lainnya juga kembali ke jalan tengah sehingga bertemu bersama-sama di pertengahan jalan. ${ }^{33}$

3. Perubahan Structural

Model ini menjelaskan bahwa konflik, beserta taktik-taktik yang digunakan untuk mengatasinya, menghasilkan residu. Residu ini berupa perubahanperubahan yang terjadi baik pada pihak-pihak yang berkonflik maupun masyarakat di mana mereka tinggal. Residu kemudian mendorong perilaku contentious lanjutan, yang levelnya setara atau lebih tinggi, dan mengurangi usaha untuk mencari resolusi konflik. Ada tiga macam bentuk perubahan structural, yaitu: pertama, berubahan psikologis; kedua, perubahan dalam

${ }^{32}$ Mulkan "Membongkar Praktik Kekerasan", 44

${ }^{33}$ Yusuf Qardhawi, Islam Ekstrem (Bandung: Mizan, 1993), 128 lihat juga dalam Lib-ForAll Foundation, Ilusi Negara Islam: Ekspansi Gerakan Islam Transnasional di Indonesia (Jakarta: The Wahid Institute, 2009),46-47. 
kelompok dan kolektif lainnya; dan yang ketiga, perubahan dalam masyarakat di sekeliling pihak yang berkonflik. ${ }^{34}$

Dean G. Pruitt mendefinisikan eskalasi sebagai "the use of increasingly harsh tactics” (penggunaan taktik yang semakin keras). Eskalasi juga berarti semakin luasnya sasaran atau wilayah konflik, atau semakin banyaknya orang-orang yang terlibat, atau semakin canggihnya alat-alat konflik yang digunakan. ${ }^{35}$ Jika dilihat dari sejarah umat manusia, konflik dan kekerasan sesungguhnya bukanlah hal yang baru. Ia ada sejak menusia itu sendiri muncul di permukaan bumi. Latief sebagaimana dikutip oleh Zubir menyebutkan bahwa kekerasan justru dianggap bagia dari budaya masyarakat.. bahkan kajian-kajian historis, semuanya tidakpernah menyangkal bahwa kekerasan telah ada sejak adanya manusia sehingga kekerasan dapat dikatakan juga sebagai bagian dari masyarakat. Jika diamati dengan seksama, terdapat perbedaan antara konflik dengan kekerasan. Kekerasan diakibatkan oleh konflik, namun belum tentu konflik selalu mengakibatkan kekerasan. Namun dalam perkembangannya, konflik merupakan penyebab terjadinya kekerasan ${ }^{36}$ bahkan antar keduanya semakin sulit untuk dipisahkan.

Perlu dikemukakan bahwa sejak awal, "kekerasan" yang kita bicarakan sekarang merupakan terjemahan dari kata violence dalam bahasa Inggris. Ada hal yang menarik disini, bahwa kata kekerasan dalam arti ini masih nelum terdapat dalam Kamus Umum Bahasa Indonesia susunan W J. S Poerwadarminta. Dalam kamu ini kekerasan diartikan sebagai l) "sifat (hal dsb) keras; kegiatan; kekuatan dsb" dan 2) "paksa (an); kejang; kekejangan; sedangkan kata sifatnya "keras" diartikan sebagai 1) padat kuat dan tidak mudah berubah bentuknya atau tak mudah pecah; lawan lunak, empuk, lembut; dan 2) pada umumnya menyatakan sifat hal yang sangat atau lebih daripada keadaan biasa, misalnya kuat; teguh, giat, dsb. Pengertian "keras" dan "kekerasan" seperti ini -yang belum menyamakan kekerasan dengan violence- juga terdapat dalam Kamus Bahasa Indonesia susunan Sutan Mohammad Zain. ${ }^{37}$

Kekerasan dalam konteks ini merupakan kekerasan terjemahan dari violence. Kekerasan merupakan perbuatan seseorang atau kelompok orang yang menyebabkan cedera atau matinya orang lain atau menyebabkan kerusakan fisik

\footnotetext{
${ }^{34}$ Dean G. Pruit dan Jeffrey Z. Rubin, Teori Konflik Sosial, 206

${ }^{35}$ Dean G. Pruitt dan Jeffrey Z. Rubin. Teori Konflik Sosial, 139

${ }^{36}$ Zaiyardam Zubir. Budaya Konflik dan Jaringan Kekerasan: Pendekatan Penyelesaian Berdasarkan Kearifan Lokal. (Yogyakarta:INSISTPress, 2010), 20-21

${ }^{37}$ Mulkan, Membongkar Praktik Kekerasan, 20
}

FaLASIFA, Vol. 9 Nomor 1 Maret 2018 | 139 
Asnawan

atau barang orang lain ${ }^{38}$. Hal ini hamper sama dengan pengertian violence yang diberikan Webster's New World College Dictionary, yaitu "physical force used so as injure, damage, or destroy; extreme roughness of action" pengertian ini merupakan tindakan fisik yang dilakukan oleh seseorang atau sekelompok orang untuk melukai, merusak, atau menghancur orang atau harta benda dan segala fasilitas kehidupan yang merupakan bagian dari orang lain tersebut. ${ }^{39}$

Robert Audi, seperti dikutip I Marshanda Windu merumuskan violence sebagai serangan atau penyalahgunaan fisik terhadap seseorang atau binatang; atau serangan, penghancuran, perusakan yang sangat keras, kasar, kejam dan ganas atas milik atau sesuatu yang potensial dapat menjadi milik seseorang ${ }^{40}$ maupun bagi kelompok yang berkonflik. ${ }^{41}$ Dalam bahasa sehari-hari konsep kekerasan meliputi pengertian yang sangat luas mulai dari tindakan penghancuran harta benda, pemerkosaan, pemukulan, perusakan yang bersifat ritual, penyiksaan dan bahkan sampai pada pembunuhan. Menurut asal katanya, kekerasan (violence) berasal dari gabungan kata latin (violentus) yakni vis dan latus. Vis berarti daya dan kekuatan sedangkan latus berarti membawa. Merupakan sebuah ekspresi baik yang dilakukan secara fisik ataupun secara verbal yang mencerminkan pada tindakan agresi dan penyerangan pada kebebasan atau martabat seseorang yang dapat dilakukan oleh perorangan atau sekelompok orang umumnya berkaitan dengan kewenangannya yakni bila diterjemahkan secara bebas dapat diartinya bahwa semua kewenangan tanpa mengindahkan keabsahan penggunaan atau tindakan kesewenang-wenangan itu dapat pula dimasukan dalam rumusan kekerasan ini.

Secara sosiologis, kekerasan merupakan konflik sosial yang tidak terkendali oleh masyarakat dengan mengabaikan norma dan nilai sosial sehingga menimbulkan tindakan merusak. ${ }^{42}$ Sedangkan menurut Fisher yang dikutip oleh Suharno, kekerasan merupakan sesuatu yang meliputi tindakan, perkataan, sikap atau berbagai struktur dan sistem yang mengakibatkan kerusakan

${ }^{38}$ Tim Penyusun Kamus Pusat Pembinaan dan Pengembangan Bahasa, Kamus Besar Bahasa Indonesia (Jakarta: Depdikbud dan Balai Pustaka, 1988) 425

${ }^{39}$ Mulkan, Membongkar Praktik Kekerasan, 20

${ }^{40} \mathrm{I}$ Marshanda Windu, Kekuasaan dan Kekerasan menurut Johan Galtung (Yogyakarta: Kanisius, 1992), 62.

${ }^{41}$ Zubir. Budaya Konflik dan Jaringan Kekerasan, 21

${ }^{42}$ Fitri Yanti, "Kekerasan dalam Berpacaran” Skripsi (Makassar, Universitas Hasanuddin, 2012), 9

140 | Falasifa, Vol. 9 Nomor 1 Maret 2018 
secara fisik, mental, sosial dan lingkungan dan atau menghalangi seseorang meraih potensinya secara penuh. ${ }^{43}$

Robert Gurr merumuskan corak kekerasan atas beberapa tingkatan yaitu:

1. Turmoil yaitu tindakan kekerasan politis yang tidak terorganisasi dan partisipasi popular, termasuk serangan politis, kerusuhan, konflik politik dan pemberontakan kedaerahan yang relative spontan. Turmoil adalah gerakan yang bersifat spontan. Jika ada kejadian seperti pencurian, maka masyarakat langsung menghakimi, seperti mengeroyok, hingga membakar sampai mati. Hal ini biasanya bentuk sikap muak masyarakat terhadap pencuri yang merajalela selama ini sehingga ketika tertangkap basah, akumulasi sakit hati, dendam dan muak selama ini dilampiaskan secara membabi buta. Secara sporadis, bentuk kekerasan ini terjadi di tiga wilayah penelitian, yakni Aceh, Poso dan Papua.

2. Conspiracy yaitu kekerasan politis yang terorganisir rapi an pertisipasi terbatas seperti pembunuhan politis terorganisasi, terorisme dalam skal kecil, kudeta dan pemberontakan. Conspiracy merupakan tindakan kekerasan yang sudah terencana dengan baik. Dalam konspirasi, aspek organisasi, sumber dana, elite dan partisipasi dari pengikutnya sudah menjadi hal yang penting. Beberapa kejadian di Aceh, Poso, dan Papua memperlihatkan konspirasi yang dilakukan pihak luar terhadap masyarakat atau mengorbankan masyarakat, sehingga masyarakat seringkali bingung kenapa semua terjadi dan jalan keluar yang harus diambil.

3. Internal War yaitu kekerasan poltis yang terorganisasi dan partisipasi popular dari luar bertujuan untuk menumbangkan rezim tertentu, merombak Negara. Pola yang ditempuh adalah kekerasan yang ekstensif, termasuk terorisme, perang gerilya dalam skal besar, seperti perang saudara sampai kepada sebuah revolusi. Internal War adalah kekerasan politik yang telah terencana. Dalam konteks ini, kasus Aceh, Poso dan Papua, sudah sampai kekerasan pada tingkatan Internal War ini. Konflik di Aceh antara tentara dan polisi dengan Gerakan Aceh Merdeka (GAM), konflik antara Islam dan Kristen di Poso dan Konflik pengusaha, penguasa dan masyarakat di Papua memperlihatkan jaringan kekerasan sudah berlangsung di tiga tempat ini.

Kekerasan di tiga tempat ini menimbulkan ribuan orang meninggal dan milyaran kerugian materi sehingga sudah sampai pada tahap Civil Wor. Mereka yang berperang itu sesungguhnya merupakan warga sipil yang tidak dipersenjatai. Namun, jumlah yang banyak mereka miliki dapat menimbulkan korban dalam

\footnotetext{
${ }^{43}$ Suharno, "Konflik, Etnisitas dan Integrasi Sosial", 2
}

FaLASIFA, Vol. 9 Nomor 1 Maret 2018 | 141 
Asnawan

jumlah yang besar, terutama melalui pembakaran-pembakaran yang mereka lakukan di kedua belah pihak. Dalam Internal War ini sudah banyak persoalan yang mengikutinya, seperti provokator, pimpinan, pembakaran, sampai pada tahap pembunuhan missal. Kasus Aceh, Poso, dan Papua merupakan contoh yang menarik dari bentuk Internal War. Beberapa peristiwa yang terjadi di tiga daerah ini memperlihatkan tingginya tingkat kekerasan. Bahkan, untuk Aceh disebut sebagai bangsa yang memiliki "tradisi sejarah perang" yang panjang.

\section{KESIMPULAN}

Ada beberapa faktor yang menjadi penyebab kerusuhan di Puger yang saling berkaitan, dan tidak berdiri sendiri, pertama adalah perselisihan kedua kelompok Barat dan Timur yang memiliki faham keagamaan berbeda, dan sudah terjadi sejak lama. kedua, penyelenggaraan karnaval yang tidak diizinkan aparat kepolisian, hingga menyebabkan tindak pidana perusakan dan penganiayaan. ketiga, adanya kemungkinan provokasi dari pihak luar, keempat, dikarenakan adanya faham dan ajaran syi'ah -karena memang ajaran tersebut sangat berpotensi menimbulkan gesekan dan keresahan masyarakat di kecamatan Puger khususnya di desa Puger Kulon dan sekitarnya- sebagamana faham dan ajaran yang disebarkan oleh barat. Beberapa upaya resolusi konflik Sunni-Syiah yang ditempuh oleh berbagai kalangan pasca konflik, antara lain: 1) rapat koordinasi di tingkat muspida dengan melibatkan berbagai elemen dalam rangka meredam konflik yang lebih luas; 2) meningkatkan intensitas komunikasi antar etnis dan golongan dalam upaya mengantisipasi isu-isu yang sifatnya provokatif; 3) menindak tegas para pelaku dan otak kerusuhan melalui upaya mencari, menahan/menangkap serta menghukum sesuai dengan undang-undang dan hukum yang berlaku; 4) menghimbau kepada masyarakat Puger khususnya desa Puger Kulon agar tetap tenang dan sabar dan untuk masa-masa yang akan datang 5) memberikan bantuan kepada korban atas kerugian harta benda maupun jiwa.

\section{DAFTAR PUSTAKA}

Ayu Sutarto, Menjadi NU Menjadi Indonesia, Jember, Kopyawisda Jatim, 2005.

Abdul Munir Mulkan, dkk, Membongkar Praktik Kekerasan: Menggagas Kultur

Nir-Kekerasan, Malang: Universitas Muhammadiyah Malang, 2002.

Afif Muhammad, Agama \& Konflik Sosial, Bandung: MARJA, 2013.

Alpha Amirrachman. Revitalisasi Kearifan Lokal, Jakarta Selatan: ICIP, 2007.

Dean G. Pruitt dan Jeffrey Z. Rubin. Teori Konflik Sosial, Yogyakarta: Pustaka Pelajar, 2004.

142 | FALASIFA, Vol. 9 Nomor 1 Maret 2018 
Relasi Konflik dan Agama...

Hasrullah, Dendam Konflik Poso, Jakarta: Gramedia Pustaka Utama, 2009.

Mulkan, Abdul Munir Mulkan, dkk, Membongkar Praktik Kekerasan: Menggagas Kultur Nir-Kekerasan, Malang: Universitas Muhammadiyah Malang, 2002.

Robert Alexander, Konflik Antar Entis dan Penanggulangannya, Tesis Universitas Diponegoro, Semarang, 2005.

Sandi Suwardi Hasan, Konflik Sosial dan Urgensi Dialog Agama, al-'Adalah, 2 Jember: STAIN Press, 2007.

Slamet Sutrisno, Filsafat dan Ideologi Pancasila, Yogyakarta: ANDI, 2006.

Komisi untuk Orang Hilang dan Korban Tindak Kekerasan (KontraS), "Keadilan Macet, Kekerasan Jalan Terus: Laporan Tahunan Kondisi HAM di Indonesia 2012.

Ihsan dkk, Pola-pola Konflik Keagamaan di Indonesia (1990-2008), (hasil penelitian yang bekerjasama Yayasan Wakaf Paramadina (YWP) Magister Perdamaian dan Resolusi Konflik, Universitas Gadjah Mada (MPRK-UGM), The Asia Foundation (TAF), Jakarta, 2009.

Imam B. Jauhari, Teori Sosial: Proses Islamisasi dalam Sistem Ilmu Pengetahuan, Yogyakarta: Pustaka Pelajar, 2012.

http://alislamiyah.uii.ac.id/2013/08/22/menguak-akar-kekerasan-bernuansagama/\#_ftn4 lihat juga The Wahid Institute, "Lampu Merah Kebebasan Beragama”, Laporan Kebebasan Beragama dan Toleransi di Indonesia, (Jakarta: The Wahid Institute, 2011.

Ibnu Katsir, Kisah Habil dan Qabil (Dar Al-Manarah) dalam ebook www.Islambasics.com

Tim Balai Litbang, Mencari Solusi Konflik dan Kekerasan Internal Umat Islam dalam http://www.balitbangdiklat.kemenag.go.id/sinopsis-hasilpenelitian/kehidupan-beragama/283-mencari-solusi-konflik-dan-kekerasaninternal-umat-keragama.html

Rizqon Khamami, Tashwirul Afkar (Jakarta Selatan: LAKPESDAM dan TAF, 2004), 41 edisi nomor 17. Selain itu, Harun Nasution, dalam Islam Ditinjan dari Berbagai Perspektif Jakarta: Universitas Indonesia Press, 2002.

M. Atho Mudzhar, "Lingkungan Dan Peran Strategis Fkub Dalam Pemeliharaan Kerukunan Umat Beragama Dan Persatuan Nasional” dalam ,http://balitbangdiklat.kemenag.go.id/indeks/artikel-ilmiah/593-lingkungan-dan-peran-strategis-fkub.html

Tim Balai Litbang, Konflik-konflik Sosial Bermuansa SARA di Berbagai Kommnitas. Dalamhttp://www.balitbangdiklat.kemenag.go.id/sinopsis-hasilpenelitian/kehidupan-beragama/172-konflik-konflik-sosial-bernuansa-saradi-berbagai-komunitas-studi-kasus-kerusuhan-mataram-januari-2000.html

ҒALASIFA, Vol. 9 Nomor 1 Maret 2018 | 143 
Asnawan

Syafuan Rozi, Kekerasan Kommnal:Anatomi dan Resolusi Konflik di Indonesia Yogyakarta: Pustaka Pelajar, 2006.

Syafuan Rozi dkk, Kekerasan Kommnal, Yogyakarta: Pustaka Pelajar, 2004.

Suharno makalah yang disampaikan dalam Seminar dan Lokakarya Resolusi Konflik pada Civics Community, Konflik, Etnisitas dan Integrasi Sosial, Universitas Negeri Yogyakarta, 2006.

Robby I. Candra, Konflik dalam hidup sehari-hari, Kanisius, Yohyakarta, 1992.

Nurman Said, Masyarakat Muslim Makasar, Jakarta: Badan Litbang dan Diklat Departemen Agama RI, 2009.

Yusuf Qardhawi, Islam Ekstrem, Bandung: Mizan, 1993.

Lib-For All Foundation, Ilusi Negara Islam: Ekspansi Gerakan Islam Transnasional di Indonesia, Jakarta: The Wahid Institute, 2009.

Zaiyardam Zubir. Budaya Konflik dan Jaringan Kekerasan: Pendekatan Penyelesaian Berdasarkan Kearifan Lokal. Yogyakarta: INSIST Press, 2010.

Tim Penyusun Kamus Pusat Pembinaan dan Pengembangan Bahasa, Kamus Besar Bahasa Indonesia, Jakarta: Depdikbud dan Balai Pustaka, 1988.

Marshanda Windu, Kekuasaan dan Kekerasan menurut Johan Galtung, Yogyakarta: Kanisius, 1992.

144 | ҒALASIFA, Vol. 9 Nomor 1 Maret 2018 